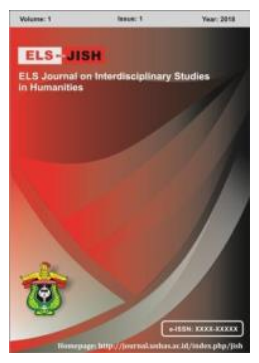

ELS-JISH

ELS Journal on Interdisciplinary Studies on Humanities

Volume 3 Issue 2, 2020

ISSN (print) : 2621-0843

ISSN (online) : 2621-0835

Homepage : http://journal.unhas.ac.id/index.php/jish

\title{
The Function of Proverbs as Educational Media: Anthropological Linguistics on Wolio Proverbs
}

\author{
Firman Alamsyah Mansyur ${ }^{1}$, La Ode Achmad Suherman²
}

1firman.alamsyah@umbuton.ac.id

\begin{abstract}
This study aims to explain the function of proverbs as an educational media in the sociocultural life of Wolio people in Southeast Sulawesi. The method used in this study is a descriptive qualitative in anthropological linguistics. Data collected through observation and indepth interviews. Data analysis departs from language analysis and then cultural analysis. This study concludes that Wolio proverb as an educational media has five important functions in the social life of Wolio people, namely as a means to: (1) teach linguistic knowledge, (2) train the performance of Wolio young people in speaking, (3) instill values wisdom for young people, (4) controlling young people's behavior to conform to agreed norms, and (5) educating Wolio youths to own and uphold their life principles. From these findings, this study confirms that proverbs are a good educational media because it contains linguistic knowledge and positive cultural values so that they must be kept and preserved by their supporting communities. The role of the government is very important to support the preservation of this proverb.
\end{abstract}

Keywords: Proverbial Function, Anthropological Linguistics, Wolio

How to cite: Mansyur, F. A., \& Suherman, L.O.A. (2020). The Function of Proverbs as Educational Media: Anthropological Linguistics on Wolio Proverbs. ELS Journal on Interdisciplinary Studies in Humanities, 3(2), 271-286. DOI: 10.34050/els-jish.v3i2.10505

\section{Introduction}

The oral tradition has been the primary means of contact between society and culture (Rahman, 2017). Wolio Proverb is one of the oral traditions of Wolio people in Southeast Sulawesi Province, Indonesia. In communicating, Wolio people use the Wolio language. The Wolio language is an Austronesian family, or Polynesian Malay, a sub-group of Muna-Buton (Language Center, 2008; SIL: 2006). Wolio is one of the languages whose status is threatened with extinction (Ethnoloque Languange of The World, 2016). The Wolio people live in the city of Baubau, which was once the center of the kingdom and sultanate of Buton. In the past, Wolio language was used as a lingua franca in areas that were part of the kingdom of Buton that had their own mother tongue, for example: Pancana on Muna island, Liwuto is used on the island of blacksmith or Wakatobi, Laiwui on the island Kabaena and the North Buton mainland (See Abas et al, 1983: 2$3)$. Wolio is a type of vocalist language because there are no consonant

12 Universitas Muahmmadiyah Buton, Indonesia 
phonemes that occupy the final position of a word. In forming its syntax, Wolio language generally follows the pattern SP - (O). The Predicate $(P)$ - Subject $(S)$ pattern is very rare (Abas et al, 1983; Anceaux, 1988).

Wolio Proverb is one of the neglected oral traditions because it has not been well documented and researched (Mansyur, 2016; 2018). Fortunately, Arief, Haddade and Mulya (1992) have written a dictionary of expressions in Wolio. Even so, the dictionary is more related to idiomatic expressions that containing wisdom and not. There are still very few expressions related to proverbs. Mansyur (2018) conducted documentation and analysis of the Wolio proverb. Therefore, this study is basically a development of the study.

Study of proverbs is very important. KBBI (2005: 858) explains that proverbs are expressions in the form of groups of words or sentences that are still structured, usually affix specific purposes, including thimbles, expressions, and parables that contain advice, principles of life or rules of behavior. Proverbs have two important roles for humans, namely: (1) as a means of describing various realities in society, and (2) as a source of values that serve as guidelines for human life (Mahali and Saamah, 2013: 83).

Proverbial studies have been done by various experts in the world. Loeb (1953) examines Kuanyama Ambo's proverb in Southwest Africa and makes the following classification: (1) legal proverb, (2) ethical proverb, (3) philosophical proverb, (4) religious proverb. Furthermore, Arewa and Dundes (1964) explain that the Yoruba proverb serves to train or teach children to maintain relationships with their parents, siblings, extended family members, and older ones.

Bergsma (1970) studies the proverb of southeastern Nigerian (BenueCongo). From his study, he asserted that proverbs function as social control tools used in various situations, namely: as a means of controlling activities without the use of violence, as a means to embarrass shame, as a means to get out of difficult situations without losing face, as a means of praise, and as a means to predict the future. On the other hand, Gokhan (1992) explains that the functions of proverb in the Turkish community are to advise, gossip, criticize, illustrate, entertain, self-reflect.

In Malay proverb, Hamzah and Hasan (2011) explained that Malay proverbs are a mirror of the relationship between language and thought, as well as the height of thought and creativity of the Malay people in creating proverbs that are based on the natural surroundings. Furthermore, Nopiah et al. (2017) examines the reflection of the "durian-cocumber" dualism in Malay proverbs with an inquisitive semantic approach. This approach departs from continuous curiosity to get answers about the meaning of an expression. From their analysis, they concluded that proverbs based on the dualism of the object "durian-cucumber" showed an element of contradiction for the intended purpose. The difference in the physical structure of the two fruits caused the Malay community to reflect the power (weak-strong) conflict for the "duriancucumber" element in proverbs.

Arimi (2015) explains that Indonesian proverb has the following characteristics: construct phrases and sentences, form a permanent agreement, 
has a proportional relationship, be figurative and literal, give a message of wisdom, has a collective cognition, value the past, inheritance, form minimum peremiological functions (social, cognitive, and textual), and in the form of quotes. Furthermore, Hendrokumoro (2016) explains that Javanese proverb contains moral values which are the crystallization of Javanese thinking.

Mansyur (2020) examines the Wolio proverb which is a human body with a cognitive linguistic approach. From the results of his study, he explained that, "the mapping of human bodies in Wolio proverbs contained images of positive, negative, and neutral meanings. The meaning of the human body does not only have a specific meaning that indicated the cultural experience of an ethnic but also showed the generality that indicated the spread of proverbs from one culture to another. This study shows the relative meaning of proverb, and the universal meaning of proverb.

Different from previous studies, this study focuses on the function of Wolio proverb as an educational medium in the perspective of anthropological linguistics. Anthropological linguistic perspective is used because this study examines language by collecting it directly from the native speakers to get an understanding of the relationship between language and culture (see Danesi, 2004: 7), especially in the aspect of education. Foley (2001: 3-5) states that anthropological linguistics attempts to explain the hidden meanings behind the use of language, different forms of language, the use of registers and styles. Therefore, this study is basically an effort to express and understand the practices of the use of proverb in the social and cultural life of the Wolio people.

This anthropological linguistic study sees a close relationship between language and culture in the use of Wolio proverbs. According to Kramsch (1998: 3 ) there are three things why language and culture cannot be separated from each other, namely: (1) language express cultural reality, (2) language embodies cultural reality, (3) language symbolizes cultural reality. In this study, proverbs are understood to express the cultural reality of the speaker, proverbs are the embodiment of cultural realities, and proverbs are symbols of the cultural realities of the speakers.

One interesting idea is the concept of language relativity. This view was put forward by German scientists, Johann Herder (1744-1803) and Wilhelm von Humbolt (1762-1835 who stated that, "different people speak differently because they think differently, and that they think differently because their language offers them different ways of expressing the world arround them. "This idea was later used by American linguist Franz Boas (1858-1942), Edward sapir (1897-1941), and later Benjamin Lee Whorf (1897-1942) (Kramsch, 1998: 11). In this study the issue of language relativity refers to the question of whether the function of proverbs as educational media is relative, or is universal, but to answer these questions requires a comparative analysis with other proverbial studies.

Discussion of functions in the linguistic tradition refers to the motives or goals associated with the factors of speech events (Hymes, 1972: 116). The concept of function starts from the view of Buhler, which proposes three language functions, namely: (1) expressive function, (2) appeal function, (3) 
reprensentative function. Jakobson developed the buhler function into six language functions, namely: (1) emotive function, (2) conative function, (3) referential function, (4) poetic function, (4) phatic function, and (6) metalingual function. The function is related to six aspects, namely addresser, addresse, context, message, code, and contact. Emotive or expressive functions occur when a conversation is emphasized on the addresser. Conative functions occur when the emphasis is on the recipient factor. Referential functions occur when the emphasis is on context. Poetic function occurs when the emphasis is on massage. Phatic function occurs when the emphasis is on contact. Metalingual functions occur when the emphasis is on the code (via Tribus, 2017).

Leech (2003: 65) simplifies Jakobson's function into five, namely: (1) informational functions that refer to the subject matter, (2) expressive functions that refer to speakers / writers, (3) directive functions that refer to the listener / reader, (4) phatic functions that refer to means of communication, and (5) aesthetic functions that refer to messages.

The concept of education in the Indonesian dictionary (KBBI, 2005) means "the process of changing the attitudes and behavior of a person or group of people in an effort to mature humans through teaching and training efforts; the process, the way, the act of educating ". From this definition it can be seen that education is the practices carried out by humans as members of society to change their behavior or others through training and teaching both formally and informally so that they can become intelligent and civilized human beings according to their times or beyond their time. Therefore, education is a practice of learning that must be done by someone throughout his/her life.Laal (2011) explains that, "lifelong leaning (LLL) covers the whole spectrum of formal, nonformal and informal learning. It means that learning is a process that occurs at all times in all places. It should be a process of continuous learning that is directed towards not only providing the individual needs, also that of the relevant community.

From the description above, this study aims to see the function of proverb as an educational medium in the social and cultural life of the Wolio people. To explain this, this paper describes the function of proverbs in the educational aspect for Wolio. To avoid various interpretations of the function description it is important to refer to the context of the use of Wolio proverb, the concept of language functions of the experts, and the model of the function of the proverb from the previous studies. From this whole explanation, an understanding of the function model of proverb is then obtained as an educational media in the social life and culture of the Wolio people.

\section{Method}

This study uses descriptive qualitative methods. This study uses two research models, namely library and field research. Literature research using written sources and field research conducted in the City of Baubau, Southeast Sulawesi Province. Field data collection uses participatory observation and interview techniques: (1) relatively closed interviews, and (2) relatively open interviews (Spradley, 1997: 102). Collected Wolio proverbs are translated into orthographically written data. Data analysis of this study departs from the 
analysis of language and then culture by examining the cultural content that exists in linguistic classes (Suhandano, 2004: 21-22). Proverbial data are analyzed in several stages, namely: (1) literal and contestual translation, 2) analyzing the aspect of the linguistic and context of the use of Proverb, (3) to identify the function and classify the function of proverbs as educational media for the Wolio people by referring to the context of social-budaya, and the theory of function, and (4) make general conclusions regarding the model of understanding of proverbial function as the educational media of Wolio people.

\section{Function of Wolio Proverbs as Educational Media}

Wolio Proverb is language expressions that contains positive cultural values, especially in the educational aspect. Proverbs are the art of using language, namely how humans combine lexicon, syntax, and meaning (Djawanai 2009: 21). Therefore, the practices of the use of proverbs in a community, is a form of implementation of education in the community environment in which there is a process of learning and teaching aspects of language and positive cultural values. According to Bateson (1972: 167) humans use several ways of learning, namely: rote learning, proto learning, and deutoro learning. Rote learning is a memorization activity, proto learning is that humans always want to learn about something, and deutoro learning is learning to learn to educate themselves. Deutoro learning is a human characteristic from other creatures.

From the analysis of linguistic and cultural data, five functions of Wolio proverbs are found as educational media in the socio-cultural life of Wolio people. The five functions can be explained below.

\subsection{Means of teaching linguistic knowledge}

Wolio Proverb is a medium for teaching linguistic knowledge in the form of sentences, language styles, and lexicons. The existence of this function is based on code or commonly referred to as metalingual functions. Djawanai (2009: 11) states that human language is inherited from generation to generation and acquired and learned through the process of socialization and cultural inheritance. Humans can learn the language through the language of speech in the form of proverbs. These functions are as follows ...

\section{a. The form of proverbial sentence}

Proverb is linguistic expressions that can be either short or long sentences. Mansyur (2018) explains that proverb sentences can be in the form of minor sentences, complete sentences, equal and unequal compound sentences, and complex sentences. In this study, the form of equivalent compound sentence is shown as the following datum.

Apoyinca bulawa, apongangaranda yinta.

'(Because) He has a heart of gold, (as a result) he has a diamond soul.'

(People who have excellent behavior or noble character) 
The proverb above is an equivalent compound sentence form consisting of two equal clauses, and second clause is the result of the first clause. Clause 1 apoyinca bulawa consists of subjects, predicates, and complement, namely: $\underline{a}$ as a personal pronouns, poyinca as a predicate, and bulawa as a complement; and clause 2 apongangaranda yinta consists of $\underline{a}$ as personal pronouns, poyinca as a predicate, and yinta as a complement. The above sentence is said to contain the following semantic meaning of causation: (cause) he has a heart of gold, (as a result) he has a diamond soul.

\section{b. Lexicon}

Proverb is linguistic expressions composed of lexicons that are connected to each other to form complete meanings. Therefore, when children learn proverb, they will automatically learn to recognize and understand the lexicon, either consciously or unconsciously as Djawanai's view above. An example of the Wolio proverb lexicon can be seen in the data below.

\section{Alea katau yitu moomini minaaka imuncuna binata, ane siitumo katau imalapeaka!}

'Take the knowledge even from the mouth of an animal, if that is good knowledge!'

(In seeking knowledge, don't look at who taught it but look at the goodness of the knowledge being taught)

From the above datum, it can be seen that there is a lexicon in the form of a noun, for example: binata 'animal', katau 'knowledge', and muncuna 'mouth', or the conjunction: moomini 'though', ane 'if'. This shows that proverb is the collection of linguistic knowledge that if children learn it, it will increase the vocabulary they have or strengthen the use of their lexicon.

\section{c. Figurative language}

Wolio Proverb contains many styles of language. Therefore, children who learn proverb without realizing it automatically learn various language styles. Mansyur (2018; 225) explains the types of language styles contained in Wolio's proverbs are the style of asonance, alliteration, repetition, simile, metaphor, parallelism, paradox, and hyperbole. data below.

One example of language style in Wolio proverbs can be seen from the

Aka porango tee dadi.

'Older hearing than age.'

(A person who is younger in age if he hears lots of information will gain wider knowledge than an older person)

Proverb above shows the use of metaphorical language styles in proverbs. The metaphor uses the source domain aka porango 'older hearing' which is used to explain the target domain or tenor of person who has a lot of knowledge because he/she listens to more. Aka 'older brother' is associated with someone who first gets something rather than younger brother because he/she is born first, and porango is associated with knowledge gained by listening. 


\subsection{Means of training performance of children in languange}

The Wolio Proverb serves as a means to practice children's performance in speaking. The existence of this function can be seen from the use of proverbs as quotations. This function emphasizes the message or commonly referred to as the poetic function in Jakobson's terms. However, the emphasis of this function is not single but also related to the addresser and addressee. By using proverbs children can learn how to quote and use proverbs in their environment. Sapir (1928) explained that someone's ability to quote and use proverbs was highly appreciated positively in Gweabo society. This function can be exemplified as follows. An informant explained that since childhood he learned proverbs through parental speech at home and cultural events, where cultural figures usually quote a phrase or proverb. From this listening habit, he was finally able to speak in cultural forums, quoting these expressions or proverbs. The more expressions that he quotes usually attract the attention of many people. The ability to speak and quote makes the speaker more human, and writing especially in literary style makes humans more civilized (Gusdorf, 1965: 3-10). Examples of proverbial datum that is often cited in various activities is the following proverbs.

Poromu yinda saangu, pogaa yinda koolota.

'Gathering is not united, separation is not distance.'

(The relationship between God and humans is close but not unified and far but there is no distance)

The proverb above is a means of explaining God's relationship with humans. In the proverb above explained that the relationship between God and servant is close but not united and far but there is no distance. Linguistically, the proverb is in the form of declarative sentence, equivalent compound sentence and figurative meaning. This expression is used in formal or informal situations by adult speakers to their listeners to explain the relationship between God and servant. In informal situations, older speakers use this proverb to younger or peers but in formal situations, this proverb can be used by listeners for all ages. For example, an adult speaker in a formal or informal situation wants to explain the relationship between God and man so he can quote the proverb directly.

\subsection{Means of planting the values of wisdom}

Wolio Proverb can be used as a means to instill positive values in children's lives. This function emphasizes the speech partner or listener to be able to absorb the values inherited. This can happen because proverbs contain positive values such as:

\section{a. Value for mutual respect}

Wolio Proverb contains wisdom values that teach people to respect one another. The message can be seen in the expression below.

Poangka-angkata!

'Lifting each other up!'

(Someone should respect each other) 
The proverb above is a tool used by Wolio people to advise their interlocutors to respect each other. In language, this proverb is in the form of minor sentences. In formal situations, adults can use this expression to the second person consisting of various age levels. In informal situations, this proverb is usually used by older to younger or the same age. This is considered to meet the existing norms of politeness. For example, in a semi-formal meeting between the government, traditional leaders or cultural leaders, and youth, a traditional leader can quote the proverb by saying "as the message of our parents used to be Poangka-angkata! 'Lifting each other up'. " By using proverb, speakers hope to advise listeners to recall the message of the ancestors so that Wolio people respect each other between the young and the young, the young with the old, and between the government and cultural leaders. This can create harmony and peace in the social life of Wolio people.

\section{b. Value to improve self quality}

Wolio proverb contains educational values that teach children or young people to always improve their quality. The message can be seen in the datum below.

Tapoguru yi paiyasa.

We study in the mirror. '

(Learn to understand or teach yourself before understanding or teaching others)

Tondona mangaandeana kamatea, tondona karona yinda kamatea.

$\mathrm{He} /$ she see someone else's fence, he/she don't see the fence him/herself.'

(Someone who like to judge other person's shortcomings or weaknesses, but rarely assess their shortcomings or weaknesses)

In the socio-cultural life of the Wolio, the above expression can be used by parents to advise their children or younger interlocutors to improve their behavior or practice the knowledge they learn from themselves before they patronize others. For example, uncle sees his nephew often criticizing the actions of others in a rude way so the uncle can use the proverb to advise his nephew. With these teachings, someone can make self-introspection.

\section{c. Value for working diligently}

Wolio Proverb contains educational values that teach children to work diligently and study hard so that life can be better. These values can be seen in the datum below.

Mangule yindaaka mangule, bolimo mangule manguleaka.

'Get tired so you don't get tired, don't get tired so tired. '

(Work hard now so you don't suffer tomorrow)

The proverb above is a tool that can be used by Wolio people to advise their interlocutors to work hard when they are young so they do not suffer when they are old. Linguistically, this proverb is in the form of declarative, and equivalent compound sentences. This proverb can be used in formal and 
informal situations. In formal situations, this expression is generally used by adult speakers of younger, or peer-speaking opponents. In informal situations, this expression can be used by older people to younger or the same age. For example, an older speaker uses the phrase to advise children, a young man, to work hard.

\section{Mapi kangare tee kumbi.}

'Sick lazy rather than scabies. '

(Lazy character is a mental illness that is more difficult to overcome than physical illness)

Linguistically, the proverb above is in the form of declarative sentence and metaphorical meaning which likens laziness to diseases that are more dangerous than festering scurvy. For people Wolio scurvy can be easily treated but the lazy character will be very difficult to overcome if these traits are inherent in a person. The use of this expression is usually in an informal situation in the family. Parents can advise or even criticize their lazy children by using this expression. Lazy traits and behavior is something negative that can cause a person to become poor.

\subsection{Means to control children's behavior}

The Wolio proverb can function as a means of controlling children's behavior to conform to the norms prevailing in society. The existence of this function emphasizes on. Speakers use proverbs to control the behavior of the speech partners or in Jakobson's terms called the conative function.

\section{a. Controlling speaking behavior}

In establishing communication with others it is important for someone to speak clearly and with direction. It is intended that the message to be conveyed is easily understood and makes the interlocutor feel comfortable. Therefore, one should avoid ambiguity or ambiguity of the message to be conveyed. Criticism for people who communicate unclear and undirected can be seen in the data below.

Yapai puu, yapai lolo?

'Where are the trunks, where are the edges?'

(Someone's conversation that is difficult to understand because it is unclear what he wants to say)

The proverb above is a subtle form of criticism used by Wolio people to remind someone to communicate clearly, regularly and with direction. Linguistically, the datum above is in the form of interogative, equal compound sentences, and figurative meaning that is associated with a unclear message in conversation. With good communication, the speaker and the interlocutor can utilize space and time effectively, as well as obtain the results of good communication that is the goal.

Proverb that contain criticism of people who dominate the conversation can be seen in the data below. 
So akamundo-mundomo mboomo yikane pogo.

'He talks like a parrot fish.'

(People who talk continuously without giving others the opportunity to talk)

The above expression linguistically is a form of declarative sentence, and is figurative meaning associated with the actions of someone who dominates the conversation so that it does not provide an opportunity for the speaker to speak. For example, in an informal situation, someone comes to visit a neighbor's house and talk continuously without giving the host the opportunity to talk. After the person returns, the host can criticize the behavior of his/her guests through others by saying proverbs. In the family, parents can use the expression directly to the child who talks at length in front of his parents so that it seems to patronize their parents. With this expression, it is hoped that balanced and harmonious communication can be built.

\section{b. Behavior when eating}

Proverb teaches Wolio people not to be greedy. This behavior is considered despicable because it can make others not get their food rations, for example not getting food so that it can cause social conflict. Related datum is shown in the proverb below.

\section{Komo kandena kea-kea}

'Like eating a parrot'

(Greedy person)

The above expression is generally used to describe or criticize the behavior of someone who is considered not good. For example, an adult speaker, whether uncle or aunt, can use the proverb to his/her nephew who overeat. With this expression, it is certainly expected that there will be a change in behavior from the nephew. This description shows that there are rules that govern in the realm of food to maintain harmony between Wolio people with one another, both in the the family or the society.

\section{c. Learning behavior}

The use of proverb can control children's behavior for learning because proverbs contain motivational values so that children are enthusiastic in learning and working. The use of proverb is a form of indirect advice in which children assume the message is an ancestral message that must be followed. The use of proverb is one of the strategies of parents so that the message is easily followed by children.

Poyinca wani.

'Heart of a bee.'

(People who have a strong will)

The above datum likens person who has a strong determination like a bee heart. Wolio people must learn from the spirit of bees that live by working hard to build their homes, and be able to protect themselves and their groups from various attacks or threats that come from outside. A strong determination is an 
individual capital to succeed in working on various aspects of life. In the life of the Wolio, parents use the above expression to advise their children, praise, or describe the character of people succeeding with that expression. For example, if there are children who are diligent in learning to succeed, then parents can say poyinca wani.

\section{d. Behavior for a simple life}

Wolio Proverb contains values of simple life. Therefore, parents can control the behavior of children to live simply with proverb. Children who listen to proverbs tend not to refute their parents' advice. Therefore, values in proverbs if taught often can control the behavior of children. The related proverb can be seen below.

Yinda kae, yinda kolabi.

'Nothing less, nothing more.'

(In doing something should be appropriate for its size or commensurate)

The above proverb is a reflection and expression of the views of Wolio people about the importance of the concept of simple life. This proverb implies the parable of a simple living such as a situation that is not lacking or excessive. If reduced is considered negative because it can mean deficiency or poor and if excessive is considered negative because it means wasteful, greedy, or arrogant. This explains that the concept of a simple life according to the Wolio is to do something according to its size. For example, adult speakers (grandfather / father / grandmother / mother) see their teenage children or grandchildren cooking rice mostly or washing clothes with excessive soap so they can use the above expression to advise the child or grandchild. With these proverbs, children as individuals are expected to contemplate and make these expressions as a guide in carrying out their activities.

\section{e. Behavior to help others}

Proverbs are a means to educate children to help others or not be miser. Miser behavior is considered despicable because the person who behaves is not willing to share his/her wealth or help his/her brother/sister in need sincerely. Miser attitude is described in the expression below.

Inda limba ombuna.

'No smoke coming out.'

(Person who do not want to share his/her wealth or sustenance)

Amaseke yincana.

'He/she is narrow hearted.'

(Person who is stingy or who only think of profit and loss in doing something)

In the socio-cultural context of the Wolio people, the above proverb can be used to describe and criticize the character of someone who is considered negative. Proverbial datum (o) describe the behavior of people who do not want to give or share their wealth when others come to ask for help at a time. Datum 
(p) describe people who always think of profit and loss when giving something to others. Both of the above proverbs are often used in the social life of Wolio people to gossip about a person's negative character. Wolio people who have this attitude will become gossip, both in young people's or parents' conversation. This gossip is a punishment given in order to create an attitude of shame or fear for the perpetrators. According to L. Pospisil, one of the characteristics of traditional law or attribute of law is the attribute of sanction which can take the form of physical and spiritual sanctions, spiritual sanctions in the form of fear, shame, and feeling of being hated (through Koentjaraningrat, 1997: 23-24)

\subsection{Means to educate children to have principles of life}

The Wolio Proverb serves as a means of educating Wolio children to have and uphold their life principles. The existence of this function can be seen from the use of proverbs by speakers for the purpose of stating the principle or the motto of life they profess. This function is more oriented to the speaker. The use of proverbs as a motto is basically very closely related to the views of Mahali and Saamah (2013) which states proverbs as a guide to the life of the speaker. The use of Wolio proverbs as a means to educate children to have a principle of life can be seen in the data below.

\section{Binci-binciki kuli!}

'Pinch a little skin!'

\section{(Don't hurt others if you don't want to be hurt)}

The datum above is a form of proverb which is usually used as a means to express the principle of life so that people in Wolio behave not to hurt one another. Linguistically, the proverb is in the form of single sentences and has figurative meaning. This proverb can be used in formal and informal situations. For example, in formal situations, an adult speaker can use this expression to the second person with various age levels. In informal situations, this proverb is usually used by the older to the younger or the same age to emphasize the principle of life that should be adopted by the Wolio people.

\section{Bolimo Karo, Somanamo Lipu!}

'Do not be yourself, as long as the region!'

(Do not put personal interests first rather than the interests of the region / country)

The proverbial data above is used as a means to express the principle that someone in doing something takes precedence over the interests of the region rather than personal. Linguistically, the proverb is in the declarative and unequal compound sentences and has figurative meaning. This expression has several variations, namely: Nayinda-nayindamo karo solanamo lipu, Yinda-yindamo karo somanamo lipu, Ayinda-yindamo karo somanamo lipu, and Bolimo karo somanamo lipu. Of these variations, the expression form Nayinda-nayindamo karo solanamo lipu is considered to be more subtle than the others. However, at this time the form of the expression Bolimo karo somanamo lipu is more popular because it is easier to pronounce and remember. This proverb can be used in 
formal and informal situations. In formal situations, adult speakers are free to use this expression to the 2nd person consisting of various age levels. In informal situations, this proverb is usually used by older to younger or the same age. This follows the norms of politeness.

From the description above it can be seen that the results of the functional analysis show five Wolio proverbial function models as educational media. These functions can be explained below. First, Wolio proverb functions as means to: teach linguistic knowledge is a function based on code or in Jakobson's concept called a metalingual function. Second, the function of proverbs as a means of training the performance of young Wolio in speaking is the conative function because it refers to the listener (addresse). Third, the function of proverbs as a means of instilling wisdom values for young people is a function based on speech partners and listeners. Fourth, the function of controlling the behavior of young people to conform to agreed norms is a function that emphasizes the listener. Fifth, the function of proverbs as a means of educating Wolio young people to have and hold fast to their life principles. This function is oriented towards the speaker himself. Some functions can be oriented to several things, but the main emphasis and context related to the purpose of using proverbs in the educational aspect becomes very important.

\section{Conclusion}

The Wolio Proverb is a good educational media for Wolio people that can serve as a means to: (1) teach linguistic knowledge, (2) train the performance of young Wolio in speaking, (3) instill wisdom values for young people, (4) controlling the behavior of young people to conform to agreed norms, (5) educating Wolio youths to own and uphold their life principles. As a good educational media, Wolio proverb should be maintained and preserved by the supporting community. This study can be practically used as a reference for the government to make policies related to preservation of proverbs. Theoretically, this study contributes to the model of proverbial function as an educational media in anthropological linguistics which can contribute positively to the development of cultural linguistic studies. However, this study also has limitations because it only reveals aspects of the function of proverb in the educational aspect. The next study is expected to illustrate the function of Wolio proverbs in a broader and more detailed context. In addition, the next study can further use comparative analysis to compare the functions of proverbs in each culture, whether there is a generality or relativity of the function of proverbs in each culture. The next study is expected to illustrate the function of Wolio proverbs in a broader and more detailed context. In addition, this study can further use comparative analysis to compare the functions of proverbs in each culture, whether there is a generality or relativity of the function of proverbs in each culture. Therefore, this study is expected to provide benefits for the preservation of oral traditions, anthropological linguistics, as well as making a positive contribution to mental development for the Wolio community in Southeast Sulawesi. 


\section{Acknowledgments}

The authors would like to thank the Institute of Research and Community Service at the Universitas Muhammadiyah Buton for facilitating and providing financial assistance in this study.

\section{References}

Abas, A. A., Manyambeang, K., Nandar, I.,\& Shaidy. (1983). Struktur Bahasa Wolio. Jakarta: Pusat Pembinaan dan Pengembangan bahasa, Departemen Pendidikan dan Kebudayaan.

Anceaux, J.C. (1985). The Wolio Language: Outline of Grammatical Descriptions and Text. Netherland: Foris Publications Holland.

Arewa, E. O. \& Dundes, A. (1964). Proverb and Ethnography of Speaking Folklore. American Anthropologist, New Series 66 (6): 70-85.

Arief, A. dan M. N. Haddade, A.K. Mulya.(1992). Kamus Ungkapan WolioIndonesia. Jakarta: Pusat Pembinaan dan Pengembangan Bahasa, Dep. Pendidikan dan Kebudayaan.

Arimi, Sailal. (2016). Peribahasa Indonesia: Kajian Kategorisasi, Struktur, dan Vitalitasnya (Doctoral dissertation). Retrieved from http://digilib.fib.ugm.ac.id/digital/list_by/7/130.

Bateson, G. (1972). Steps to an Ecology of Mind. New York: Ballatine.

Bergsma, H. M. (1970). Tiv Proverb as A Means of Social Control. Journal of The International African Institute 40 (2): 151-163.

Danesi, M.(2004). A Basic Course in Anthropological Linguistics. Toronto: Canadian Scholars' Press Inc.

Djawanai, S. (2009). Language Study, Human Studies (speech inauguration of a professorship in Linguistics at the Faculty of Cultural Science, UGM). Yogyakarta: FIB UGM.

Ethnoloque Languange of The World.(2016). Wolio Language.https: //www.ethnologue.com.language/wlo. Accessed Saturday 26 October 2016, 10:30.

Foley, W. A. (2001). Anthropological Linguistics; An Introduction. Oxford: Blackwell.

Gokhan, A.(1992). What Have the Ancestor Said: An Ethnography of Speaking Proverb in a Turkish Community (Doctoral Dissertation). University of Pittsburg, Oakland.

Gusdorf, G. (1965). Speaking (La Parole). Translated by Paul T. Brockelman. Evanston, III: Northwestern University Press.

Hamzah, Z. A., Hasan \& Ahmad FM H. (2011). Language and Thought in Malay Proverbs. GEMA Online of Language Studies, 11 (3): 31-50.

Hendrokumoro. (2016). Javanese proverb (Doctoral dissertation). Retrieved from. Dissertation. http://digilib.fib.ugm.ac.id/digital/list_by/7/120. 
Hymes, D. (1972). Toward Etnographies of Communication: The Analysis of Communicative Events. P. Paolo Giglioli (Ed). Language and Social Context. England: Penguin Group.

KBBI. (2005). Pusat Bahasa (Edisi Keempat). Jakarta: PT Gramedia Pustaka Utama.

Koentjaraningrat. (1997). Kebudayaan Mentalitas dan Pembangunan. Jakarta: PT Gramedia Pustaka Utama.

Kramsch, C. (1998). Language and Culture. Oxford: Oxford University Press.

Laal, M. (2011).Lifelong learning: What does it mean ?. Social and Behavioral Sciences 28 (2011) 470 - 474.doi:10.1016/j.sbspro.2011.11.090.

Leech, G. (2003). Semantics. Yogyakarta: Pustaka Pelajar.

Loeb, E. (1952). The Function of Proverbs in The Intellectual Development of Primitive Peoples. In The Scientific Monthly, 74 (2): 100-104.

Mahali, S. N. H. and Saamah, M. R. (2013). Haiwan Sebagai Perlambangan dalam Peribahasa Orang Semai. GEMA Online of Languange Studies 13 (1): 83-98.

Mansyur, F.A. (2016). Onina Manga Mancuana Mangenge: Cultural Value of Wolio People that never Fade (A Study of Anthropological Linguistics). Proceedings of Prassati. Retrieved from 1/ pras.v0i0.1526.

Mansyur, F.A. (2018). Onina Manga Mancuana Mangenge: Traditional Wolio (Doctoral dissertation).

Retrieved from.http://digilib.fib.ugm.ac.id/digital/filter/960.

Mansyur, F. A. (2020). A Cognitive Semantics Analysis of Wolio Proverbs Related to the Human Body. Advances in Social Science, Education and Humanities Research, volume 436, Published by Atlantis Press SARL. Retrieved from https://www.atlantis-press.com/proceedings/bis-hess19/articles.

Nopiah, J., Binti, N. H Binti J., and J.B. K. (2017). Refleksi Dualisme 'DurianTimun' dalam Peribahasa Melayu: Pendekatan Semantik Inkuistif. Jurnal Linguistik 21 (2):1-14.

Language Center. (2005). Languages in Indonesia. Dendy S., Mahsun, Inyo Y. Fernandez, Kisyani Laksono, Multamia Lauder, and Nadra (Eds). Jakarta: Pusat Bahasa, Departemen Pendidikan Nasional.

Rahman, F. (2017). The revival of local fairy tales for children education. Theory and Practice in Language Studies, 7(5), 336-344.

Sapir, E. (1928). The Voice of Africa: Some Gweabo Proverbs. International African Institute 2 (2): 183-185.

SIL. (2006). Languages in Indonesia. Jakarta: SIL International.

Spradley, J.P. (1997). Metode Etnografi. Yogyakarta: Tiara Wacana Yogyakarta. 
Suhandano. (2004). Klasifikasi Tumbuh-Tumbuhan dalam Bahasa Jawa: Sebuah Kajian Linguistik Antropologis (Unpublished doctoral dissertation). Universitas Gadjah Mada. Indonesia.

Tribus (2017). The Communicative Functions of Language: An Exploration of Roman Jakobson's Theory in TESOL. Retrieved from. https://digitalcollections.sit.edu/ipp_collection/723. 